\title{
DIE METING VAN DIE VERBAND TUSSEN GESLAG EN KONFORMITEIT AS GROEPDINAMIESE VERANDERLIKES*
}

W.S. DE VILLIERS

DEPARTEMENT BEDRYFSIELKUNDE

UNIVERSITEIT VAN STELLENBOSCH
J.C.D. AUGUSTYN

DEPARTEMENT BEDRYFSIELKUNDE

RANDSE AFRIKAANSE UNIVERSITEIT

\begin{abstract}
The amount and kind of conformity induced by group pressure depend upon the nature of the situation. The nature of the group and the characteristics of the individual. In this particular study the experimental measurement of conformity developed by Asch and Crutchfield was repeated. Confirmation was found that sex operates as one of the determinants of conformity.
\end{abstract}

Menslike denke en gedrag word in 'n groot mate deur twee kragte bepaal naamlik die subtiele manifestasies van die unieke persoonlikheid aan die een kant en die invloed van die groep aan die ander kant.

Hoewel daar in die groeifase van die Bedryfsielkunde baie aandag bestee is aan die bestudering van hierdie interaksie tussen die individu en die groep (Schneider, 1976) wil dit tog uit 'n oorsig van die literatuur voorkom asof groepsgedrag nie sy regmatige plek in die kontemporêre Bedryfsielkunde plek behou nie. Gesien teen bogenoemde agtergrond is dit noodsaaklik dat sekere aspekte van groepsgedrag binne 'n bedryfsielkundige konteks herbeklemtoon moet word. Veral wanneer gedink word aan die baie sentrale rol wat die groep binne die Bedryfsielkunde vervul verdien die begrip konformiteit in besonder veel meer aandag as wat dit tans geniet.

Konformiteit word dikwels verwar met uniformiteit en konvensionaliteit (Krech, Crutchfield en Ballachey, 1962). Daar bestaan weliswaar 'n hoë mate van uniformiteit in sosiale gelowe ("beliefs"), waardes en praktyke, maar dit is nie voldoende kriteria vir konformiteit nie. Op dieselfde wyse bestaan daar ook baie gemeenskaplike houdings en opinies (byvoorbeeld die algemene aanvaarding dat die aarde rond is), maar ook dit is nouliks grond vir konformiteit.

\footnotetext{
* Versoeke vir afdrukke moet aan die eerste skrywer gerig word.
} 
Net soos in die geval van uniformiteit is verskillende vorms van konvensionaliteit ook nie voldoende grond vir konformiteit nie. Konvensionele wyses van optrede is vasgestelde wyses waarop probleme opgelos kan word en konvensies is goed geoliede groewe waarlangs sosiale gedrag kan geskied. So sou die dra van klere in ons gemeenskap geensins impliseer dat die individu 'n konformis is nie.

Die essensie van konformiteit, wat dit onderskei van uniformiteit en konvensionaliteit, is die toegee of ingee aan groepsdruk. Volgens Brown (1965) is die essensiële elemente in 'n konformiteitsituasie die aanwesigheid van twee of meer persone en 'n oordeel of opinie ten opsigte van 'n objek van gemeenskaplike belang.

Die druk wat die groep uitoefen is nie noodwendig eksplisiet nie, dit wil sê die groep hoef nie noodwendig openlik dwang op die individu uit te oefen nie. Die groepsdruk kan ook implisiet wees deurdat die bestaan van 'n groepsoordeel of aksie deur die individu waargeneem word as verskillend van sy eie en op hierdie wyse mag druk op hom uitgeoefen word. In so 'n situasie bevind die individu hom dikwels in 'n konfliksituasie en is daar vir hom basies twee rigtings van optrede moontlik. Hy mag enersyds sy eie onafhanklike opinie verklaar en dus onafhanklik van die groep bly of hy mag andersins "gedwonge" saamstem met die groep en dus konformeer.

Die werklike konformiteitsrespons kan verskillende vorms aanneem. So kan dit die vorm aanneem van duidelike openlike aksies (byvoorbeeld deelname aan stakings), 'n verbale konformiteitsrespons (die individu sê iets wat in ooreenstemming met die groepsgevoel is) of selfs vorms van gedragsinhibering (die onwilligheid om uiting te gee aan sy eie mening). As gevolg van die groot mate van individuele verskille ten opsigte van konformiteit kan daar dan ook met reg van 'n gedragskonstruk konformiteitsgeneigdheid gepraat word.

\section{Konformiteitsgeneigdheid}

Die aard en omvang van konformiteit wat deur die individu geopenbaar word hang van 'n verskeidenheid faktore af. Faktore soos die grootte van die groep (Rosenberg, 1961; Kidd, 1958; Gerard, Wilhelmy en Connoley, 1968) groepsamestelling, (Mausner, 1953, Lefkowitz, Blake en Mouton, 1955; Shaw, 1976) groepkonsensus, (Allen en Levin, 1971) sterkte van dwang (Schachter, 1951) en die groter sosiale konteks waarvan die groep deel vorm (Krech, et al., 1962) is reeds in hierdie groep verband geïdentifiseer. 
Wat die individu self betref word eienskappe soos ervaring of ondervinding ten opsigte van konformiteit (Krech, et al., 1962) persoonlikheid (Terman, in Krech et al., 1962) en geslag (Beloff, 1958) as bydraend tot die mate van konformiteitsgeneigdheid uitgesonder.

Gedurende die afgelope twee dekades is die geslagsrol in die literatuur uitgesonder as een van die uitstaande individuele determinant van konformiteitsgeneigdheid (vgl. Beloff, 1958; Krech et al., 1962; Freedman, Sears en Carlsmith, 1978). In die literatuur word die tipiese vroulike rol bestempel as afhanklik van die groep, ondergeskik aan die manlike rol en ' $n$ geneigdheid tot konflikvermyding terwille van groepsharmonie. Die gevolgtrekking sou dus met veiligheid uit die literatuur gemaak kan word dat vroulike individue meer geneig sal wees om te konformeer.

Sou laasgenoemde hipotese geldig wees hou dit sekere beroepsimplikasies vir die meer konformiteitsgeneigde persoon in aangesien navorsing reeds aangedui het dat die sodanige persone meer klem lê op konvensionele sosiale waardes en dus 'n groter belangstelling toon in beroepe soos byvoorbeeld bankier, eiendomsagent en verkoopsverteenwoordiger. (Vgl. Gough in Krech et al., 1962; Nadler, 1959).

\section{Doel van ondersoek}

Die doelstelling van die studie was om die eksperimentele werk van Asch en Crutchfield (Schneider, 1976) ten opsigte van konformiteitsgeneigdheid in ' $\mathrm{n}$ ietwat gewysigde vorm te herhaal met geslag as onafhanklike veranderlike. Bevindings in hierdie verband sou nie net interessant wees nie maar hou ook beroepsimplikasies vir die vrou in veral gesien teen die agtergrond van 'n groter beroepsbewustheid- en beroepsoriëntasie by die Suid-Afrikaanse vrou en die gepaardgaande pogings tot beter benutting van vroue-arbeid.

\section{METODE VAN ONDERSOEK}

Die benadering van Crutchfield (Schneider, 1976) is in die eksperimentele ontwerp gevolg - met enkele aanpassings. 'n Spesiale apparaat is gebou wat vyf proefpersone gelyktydig kon akkommodeer op so 'n wyse dat elkeen plaasgeneem het in 'n afskorting waar hulle nie met mekaar kon kommunikeer of op 'n ander wyse interaksie kon hê nie. Aan proefpersone is verduidelik dat hulle die response of antwoorde van elke ander groepslid op die kontrolebord wat voor elkeen aangebring is, sou kon sien. Kontroles (skakelaars) is ook voorsien waarmee elkeen sy/haar eie respons of antwoord kon weergee. Aan proefpersone is 
vervolgens verduidelik dat hulle vooraf geïdentifiseer sal word met die letters, A, B, C, D en E onderskeidelik. In die werklike eksperiment is elkeen van die vyf persone egter as E deur die navorsers geïdentifiseer sonder dat hulle daarvan bewus was en kon die response van die fiktiewe persone A tot $\mathrm{D}$ dus eksperimentee1 beheer word.

Hierdie apparaat is geplaas in 'n vertrek wat met eenrigting glas geskei was van 'n aangrensende vertrek waarvandaar die response van die fiktiewe persone A, B, C en D elektronies beheer kon word. Die response van die proefpersone $(\mathrm{E})$ is in hierdie aangrensende vertrek elektronies aangeteken.

Die probleme wat aan die proefpersone voorgehou is, was van die Sherif sowel as Asch tipe (Schneider, 1976). Daar is dus gebruik gemaak van betekenislose stimuli waarvan 'n beoordeling gemaak moes word sowel as van visuele persepsie-items. By elke groep proefpersone is die (foutiewe) response van (fiktiewe) persone A, B, C en D eers elektronies voorsien en dan is proefpersoon E gevra om sy antwoord te voorsien. Dit dien hier gemeld te word dat foutiewe response we1 sporadies afgewissel is met korrekte response ten einde ' $n$ sekere mate van geloofwaardigheid in die eksperiment by proefpersone op te bou.

Enkele voorbeelde van die betekenislose items wat in die eksperiment gebruik is word in Tabe1 1 aangedui.

TABEL 1

VOORBEELDE VAN STIMULUSITEMS WAT IN DIE EKSPERIMENT GEBRUIK IS

\begin{tabular}{|c|c|}
\hline ITEM/VRAAG & RESPONSIOONTLIKHEID \\
\hline $\begin{array}{l}\text { * Was Rooseveldt 'n "groot president? } \\
\text { * Wat is die korrekte spelwyse } \\
\text { * Hoeveel swart vakbonde is daar in } \\
\text { Suid-Afrika? } \\
\text { * Wie het die hoofrol vertolk in die } \\
\text { film "The Student Prince" } \\
\text { ** Watter lyn is die langste }\end{array}$ & $\begin{array}{l}\text { Ja of Nee? } \\
\text { Vleuel of Vleul? } \\
0 \text { of } 30 ? \\
\text { Edmund Purdom? } \\
\text { A of B? }\end{array}$ \\
\hline
\end{tabular}




\section{Proefpersone}

140 Manlike en 60 vroulike tweedejaar studente in die Bedryfsielkunde is in die ondersoek gebruik. Ouderdomme het gewissel tussen 18 en 24 jaar en die subgroepsamestelling (veral in terme van mans en dames) is op 'n toevallige wyse gedoen. Die 200 proefpersone is in subgroepe van 5 per sessie gedurende 40 sessies aan die eksperiment onderwerp.

\section{RESULTATE VAN DIE ONDERSOEK}

Gedurende die 40 sessies is 'n totaal van 810 response vanaf die 200 proefpersone verkry, waarvan 495 konformeringsresponse en 315 nie-konformeringsresponse was. Die onderverdeling van hierdie response tussen mans en dames en die daaropvolgende statistiese verwerking word in Tabel 2 saamgevat.

\section{TABEL 2}

DIE VERBAND TUSSEN GESLAG EN KONFORMITEIT

\begin{tabular}{|c|c|c|c|}
\hline \multirow{2}{*}{ GESLAG } & \multicolumn{2}{|c|}{ MATE VAN KONFORMITEIT } & \multirow{2}{*}{$X^{2}$} \\
\cline { 2 - 3 } & $\begin{array}{c}\text { Aantal } \\
\text { Konformeringsresponse }\end{array}$ & $\begin{array}{c}\text { Aantal nie- } \\
\text { konformeringsresponse }\end{array}$ & \\
\hline Mans & 337 & 258 & $18,31^{*}$ \\
\hline Dames & 158 & 57 & \\
\hline $\mathrm{p}<, 001$
\end{tabular}

Na die toepassing van Yates se korreksie vir kontinuïteit (Hays, 1973) is daar gevind dat dames beduidend meer geneig is om te konformeer as mans $\left(X^{2}(1)=18,31, p<, 001\right)$. Hierdie resultaat bevestig vorige navorsing wat soortgelyke resultate aangedui het (vergelyk Beloff, 1958).

\section{GEVOLGTREKKINGS EN AANBEVELINGS}

Hoewel vooraf kennis van sekere items weliswaar die resultate sou kon beïnvloed het is die verkeerde respons doelbewus voorsien en het 'n aansienlike mate van konformering aan 
die groepsoordeel steeds voorgekom. Meer spesifiek was dames geneig om beduidend meer as mans te konformeer wanneer hulle aan groepsdruk blootgestel is.

Hierdie eksperimentele ontwerp bied die geleentheid om ook die rol van ander determinante van konformering soos ouderdom opvoedkundige peil en kulturele agtergrond te ondersoek. Daar word dan ook aanbeveel dat, teneinde sekere aspekte van die groepsdinamika te herbeklemtoon binne die Bedryfsielkunde, voortgegaan word met veral die bestudering van die rol van konformiteit in menslike gedrag.

\section{OPSOMMING}

In die sosiale bedryfsielkunde is die invloed van die groep op die individu een van die vernaamste studieterreine. Die mate waarin ' $n$ individu konformeer tot groepsdruk hang af van die aard van die situasie, die aard van die groep en die eienskappe van die individu. In hierdie studie is die eksperimentele meting van konformiteit soos ontwikkel deur Asch en Crutchfield herhaal en bevestiging is gevind dat geslag een van die individuele determinante van konformiteit is.

\section{VERWYSINGS}

Allen, V.L., Levin, J.M. Social support and conformity: the role of independent assessment of reality. Journal of Experimental Social Psychology, 1971, 7, 48-58.

Beloff, H. Two forms of social conformity, acquiescence and concentionality. Journal of Abnormal and Social Psychology, 1953, 48, 503-506.

Brown, R. Social Psychology. New York: Collier MacMillan, 1965.

Freedman, J.L., Sears, D.O. \& Carlsmith, J.M. Social Psychology. Englewood Cliffs: Prentice Hall, 1978.

Gerard, H.B., Wilhelmy, R.A. \& Connolley, E.S. Conformity and group size. Journal of Personality and Social Psychology, 1968, 8, 79-82.

Hays, W.L. Statistics for the Social Sciences, New York: Holt, Rinehart and Winston, 1973.

Kidd, J.S. Social influence phenomena in a task orientated group situation. Journal of Abnormal and Social Psychology, 1958, 56, 13-18.

Krech, D., Crutchfield, R.S. \& Ballachey, E.L. Individual in Society. New York: McGrawHill, 1962.

Lefkowitz, M., Blake, R.R. \& Mouton, J.S. Status factors in pedestrian violation of traffic signals. Journal of Abnormal and Social Psychology, 1955, 51, 704-706.

Mausner, B. Studies in social interaction, effect of variation in one partner's prestige on the interaction of observer pairs. Journal of Applied Psychology, 1953, 37, 391-393.

Nadler, E.B. Yielding, authoritarianism and authoritarian ideology regarding groups. Journal of Abnormal and Social Psychology, 1959, 58, 408-410.

Rosenberg, L. Group size, prior experience and conformity. Journal of Abnormal and Social Psychology, 1961, 63, 436-437.

Schachter, S. Deviation, rejection and communication. Journal of Abnormal and Social Psychology, 1951, 46, 190-207. 
Schneider, D.J. Social Psychology. Reading Mass: Addison Wesley, 1976.

Shaw, M.E. Group Dynamics: The Psychology of Small Group Behavior. McGraw-Hill, 1976. 